\title{
Dynamics of extracellular enzyme activities in seawater under changed atmospheric $\mathrm{pCO}_{2}$ : a mesocosm investigation
}

\author{
C. Arnosti ${ }^{1, *}$, H. P. Grossart ${ }^{2}$, M. Mühling ${ }^{3,4}$, I. Joint ${ }^{4}$, U. Passow ${ }^{5,6}$ \\ ${ }^{1}$ Department of Marine Sciences, University of North Carolina, Chapel Hill, 27599 North Carolina, USA \\ ${ }^{2}$ Leibniz Institute of Freshwater Ecology and Inland Fisheries, 16775 Neuglobsow, Germany \\ ${ }^{3}$ Institute of Biological Sciences, TU Bergakademie Freiberg, 09599 Freiberg, Germany \\ ${ }^{4}$ Plymouth Marine Laboratory, Prospect Place, The Hoe, Plymouth, PLI 3DH, UK \\ ${ }^{5}$ Alfred-Wegener Institute for Polar and Marine Research, 27575 Bremerhaven, Germany \\ ${ }^{6}$ Marine Sciences Institute, University of California, Santa Barbara, 93106 California, USA
}

\begin{abstract}
As part of the PeECE II mesocosm project, we investigated the effects of pCO2 levels on the initial step of heterotrophic carbon cycling in the surface ocean. The activities of microbial extracellular enzymes hydrolyzing 4 polysaccharides were measured during the development of a natural phytoplankton bloom under pCO2 conditions representing glacial (190 $\mu \mathrm{atm})$ and future $(750 \mu \mathrm{atm})$ atmospheric pCO2. We observed that (1) chondroitin hydrolysis was variable throughout the pre-, early- and late-bloom phases, (2) fucoidanase activity was measurable only in the glacial mesocosm as the bloom developed, (3) laminarinase activity was low and constant, and (4) xylanase activity declined as the bloom progressed. Concurrent measurements of microbial community composition, using denaturing-gradient gel electrophoresis (DGGE), showed that the 2 mesocosms diverged temporally, and from one another, especially in the late-bloom phase. Enzyme activities correlated with bloom phase and $\mathrm{pCO} 2$, suggesting functional as well as compositional changes in microbial communities in the different pCO2 environments. These changes, however, may be a response to temporal changes in the development of phytoplankton communities that differed with the pCO2 environment. We hypothesize that the phytoplankton communities produced dissolved organic carbon (DOC) differing in composition, a hypothesis supported by changing amino acid composition of the DOC, and that enzyme activities responded to changes in substrates. Enzyme activities observed under different $\mathrm{pCO} 2$ conditions likely reflect both genetic and population-level responses to changes occurring among multiple components of the microbial loop.
\end{abstract}

KEY WORDS: Enzyme $\cdot$ Carbon cycle $\cdot \mathrm{pCO}_{2}$ changes $\cdot$ Microbial loop

\section{INTRODUCTION}

The effects of increased atmospheric $\mathrm{pCO}_{2}$ on marine ecosystems are likely to be complex and profound (e.g. Vezina \& Hoegh-Guldberg 2008, Doney et al. 2009). The dissolution of anthropogenic $\mathrm{CO}_{2}$ in the surface waters of the global ocean has already changed seawater chemistry, resulting in an increase in the concentration of dissolved inorganic carbon (DIC) and a decline in $\mathrm{pH}$ (Caldeira \& Wickett 2003, Orr et al. 2005). Changes in the carbonate chemistry of the ocean may have consequences for many biological processes, potentially changing ecosystem functioning and biogeochemical cycling of elements in the oceans (Arrigo 2007, Riebesell et al. 2008, Doney et al. 2009).

The impacts of increased atmospheric $\mathrm{pCO}_{2}$ on pelagic organisms that precipitate calcium carbonate (e.g. coccolithophores) are the focus of intense investigation (e.g. Riebesell et al. 2000, Rost \& Riebesell 2004, Fabry 2008, Iglesias-Rodriguez et al. 2008, Ries et al. 2009). In contrast, the potential impacts of higher concentrations of DIC and lower $\mathrm{pH}$ on marine prokary- 
otes have not received the same high level of attention (see also Liu et al. 2010, Joint et al. 2011). Because a large fraction of marine organic matter is processed by microbes (Azam 1998, Pomeroy et al. 2007), this lack of knowledge is a major gap in our ability to predict the consequences of increased atmospheric $\mathrm{pCO}_{2}$ for carbon cycling and the biological pump. The effects may be many-fold: a changed marine carbonate system may impact bacterial physiology, or select for specific bacterial taxa with unique characteristics or habitat preferences. The composition and/or bioavailability of organic matter may be affected through direct structural modifications, or via effects on microbial uptake or processing of organic substrates. Moreover, prokaryotic responses to changes in atmospheric $\mathrm{pCO}_{2}$ are likely to be shaped by factors that include phytoplankton responses to a changing environment. Phytoplankton provide, directly or indirectly, most of the organic matter ultimately consumed by marine heterotrophic prokaryotes - as particulate organic matter and as exudates, including dissolved organic carbon (DOC) and transparent exopolymeric particles (TEP). The responses of phytoplankton and bacteria should thus be considered in concert when investigating the effects of changes in atmospheric $\mathrm{pCO}_{2}$ on carbon cycling processes.

The PeECE mesocosm experiments (Pelagic Ecosystem $\mathrm{CO}_{2}$ Enrichment Study; http://peece.ifm-geomar. de/) (Riebesell et al. 2008) were intended to examine the community effects of changed atmospheric $\mathrm{pCO}_{2}$ during the development of a phytoplankton bloom in enclosed environments. By using a series of 9 large $\left(20 \mathrm{~m}^{3}\right)$ outdoor enclosures in Raunefjord $\left(60.3^{\circ} \mathrm{N}, 5.2^{\circ} \mathrm{E}\right)$ at the Large Scale Facility in Bergen, Norway, perturbations of carbonate chemistry could be created in an environment that supports the complexity of natural water column communities. During PeECE II, atmospheric $\mathrm{CO}_{2}$ concentrations and initial water chemistry were adjusted to represent glacial $(190 \mu \mathrm{atm})$, present day $(370 \mu \mathrm{atm})$, and future $(750 \mu \mathrm{atm})$ conditions. Nutrients were then added to each mesocosm to induce phytoplankton blooms, and the responses of bacteria, phytoplankton and zooplankton to altered $\mathrm{pCO}_{2} / \mathrm{pH}$ were investigated (Grossart et al. 2006a, Engel et al. 2008).

In the present study, we report the effects of changed atmospheric $\mathrm{pCO}_{2}$ on the initial step in heterotrophic processing of polymeric organic matter, as reflected by the activities of microbial extracellular enzymes. Extracellular enzymes were a focus of this study because heterotrophic prokaryotes can transport only small (<700 Da; Weiss et al. 1991) substrates across their membranes. The activities, as well as the structural specificities, of the enzymes that hydrolyze highmolecular-weight substrates are thus key factors determining the extent to which marine organic matter is available as microbial substrates (Arnosti 2004). The activities of polysaccharide-hydrolyzing enzymes were studied because carbohydrates are major components of algal biomass and of particulate and dissolved organic carbon (Painter 1983, Hedges et al. 1988, Benner et al. 1992). Carbohydrates are also important constituents of TEP, which play a key role in particle coagulation and can help to mediate the flux of sinking organic carbon in the ocean (Passow 2002, Grossart et al. 2006b).

Extracellular enzyme activities have been investigated previously in mesocosm experiments as well as during phytoplankton blooms under natural conditions (e.g. Nausch et al. 1998, Fajon et al. 1999, Grossart et al. 2006a, Murray et al. 2007, Piontek et al. 2010). However, with the exception of a single study (Murray et al. 2007), all of these investigations have used lowmolecular-weight proxies, consisting of a monosaccharide (or amino acid) linked to a fluorophore to measure potential enzyme activities. Low-molecular-weight substrate proxies lack the 3-dimensional size and structure of true biopolymers, so the precise relationship between rates measured using proxies and the hydrolysis of the corresponding polysaccharides is uncertain (Warren 1996). Moreover, only limited information is obtained because these substrate proxies were designed as targets for exo-acting extracellular enzymes that cleave terminal units from oligomer and polymer chains - in this case, releasing the fluorophore. The activities of endo-acting (mid-chain cleaving) extracellular enzymes are not measured, neither are the activities of enzymes that cleave (for example) polysaccharides containing a mixture of different types of monosaccharide subunit (i.e. heterogeneous polysaccharides).

To investigate the effect of changes in $\mathrm{pCO}_{2}$ on specific extracellular enzyme activities, we measured the hydrolysis rates of 4 polysaccharides differing in structure and composition. Measurements were made during the initiation, early bloom development, and late bloom development in 2 mesocosms representing glacial and future $\mathrm{pCO}_{2}$ conditions. Chondroitin sulfate, fucoidan, laminarin, and xylan were selected as substrates because the enzymes hydrolyzing these polysaccharides have been shown to occur in marine bacteria (e.g. Davis 1992, Brown \& Kelly 1993, Arnosti \& Repeta 1994) and genes corresponding to these enzymes have also been identified in the genomes of fully-sequenced marine bacteria (Glöckner et al. 2003, Bauer et al. 2006, Weiner et al. 2008). Chondroitin sulfate is a mixed polysaccharide of $N$-acetylgalactosamine and glucuronic acid. Fucoidan is a sulfated fucose-containing polysaccharide, derived from macroalgae Fucus spp., whose chemical composition mirrors that of transparent exopolymeric particles (Zhou et al 
1998). Laminarin (a $\beta(1,3)$-glucose polysaccharide) is a common storage product of diatoms and other algae, and xylan $(\beta(1,4)$-xylose) is found in red algae and terrestrial plants (Bold 1985). In order to assess the extent to which the dynamics of enzymatic activities over the development of the blooms were related to changes in composition or activity of the overall microbial community, microbial community composition and cellular production were also monitored.

For the first time, enzyme activity has been measured in an experiment initiated with a natural phytoplankton community. Differences in atmospheric $\mathrm{pCO}_{2}$ and resulting changes in seawater community dynamics and chemistry were the principal variables in our experiment. We hypothesized that the spectrum and/ or rates of extracellular enzyme activities would differ between mesocosms under differing $\mathrm{pCO}_{2}$ conditions, due to resultant changes in phytoplankton and/or bacterial communities, and possibly due to differences in seawater $\mathrm{pH}$.

\section{MATERIALS AND METHODS}

Experimental set-up, bloom development, and sampling. Details of the experimental design and sampling of the 9 large $\left(20 \mathrm{~m}^{3}, 9.5 \mathrm{~m}\right.$ deep) mesocosms during the PeECE II experiment (May 2003) at the Large Scale Facility in Bergen, Norway $\left(60.3^{\circ} \mathrm{N}, 5.2^{\circ} \mathrm{E}\right)$, are given in Grossart et al. (2006a). In brief, initial $\mathrm{pCO}_{2}$ was adjusted to glacial $(190 \mu \mathrm{atm})$, present $(370 \mu \mathrm{atm})$ and future $(750 \mu \mathrm{atm})$ atmospheric $\mathrm{pCO}_{2}$ levels by bubbling with $\mathrm{CO}_{2}$-adjusted air, i.e. air with added $\mathrm{CO}_{2}$ or air that was stripped of $\mathrm{CO}_{2}$ (Riebesell et al. 2008). In the experiments we describe in this paper, logistical constraints meant that enzymatic hydrolysis rates could be measured in only 2 of the mesocosms, so we selected the treatments with the greatest contrast in $\mathrm{pCO}_{2}$ conditions: the future (M1) and glacial (M7) mesocosms.

Fresh water was added to the upper $4 \mathrm{~m}$ of the water columns to create a pycnocline to separate surface and bottom water in the mesocosm. Nutrients were added (9 $\mu \mathrm{mol} \mathrm{l^{-1 }} \mathrm{NO}_{3}{ }^{-}, 0.5 \mu \mathrm{mol} \mathrm{l}^{-1} \mathrm{PO}_{4}{ }^{3+}$, and $12 \mu \mathrm{mol} \mathrm{l}{ }^{-1}$ $\mathrm{Si}(\mathrm{OH})_{4}$ ) to initiate bloom development. Mesocosm $\mathrm{pH}$ was measured daily over the course of PeECE II and also calculated from measurements of $\mathrm{pCO}_{2}$ and alkalinity. Water in the future mesocosm was at $\mathrm{pH} 7.8$ on Day 0 (after $\mathrm{CO}_{2}$ equilibration), and $\mathrm{pH}$ slowly increased to 7.9 on Day 10; by Day 13 the $\mathrm{pH}$ was 8.0 and remained at this value throughout the rest of the experiment. In the glacial mesocosm, $\mathrm{pH}$ was very close to 8.3 throughout the experiment. Integrated water samples from the upper $4 \mathrm{~m}$ were collected using a long polyethylene tube (diameter $10 \mathrm{~cm}$ ) that was open as it was lowered through the water column and then sealed with rubber stoppers to retrieve the sample.

Phytoplankton abundance and composition, as well as the exact timing of peak phytoplankton abundance, were different between $\mathrm{CO}_{2}$ treatments (Engel et al. 2008). Phytoplankton blooms developed in both mesocosms, with cell counts in the future mesocosm reach-

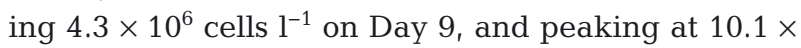
$10^{6}$ cells $1^{-1}$ on Day 17. Initially, coccolithophores, especially Emiliania huxleyi, dominated the future mesocosm phytoplankton, but by Day 15 diatoms contributed almost equally to total cell numbers. The glacial mesocosm, in contrast, was dominated by small autotrophic nanoflagellates. In the glacial mesocosm, cell counts reached $4.0 \times 10^{6}$ cells $\mathrm{l}^{-1}$ on Day 9, and

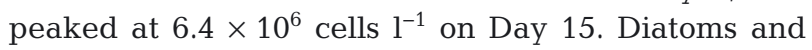
coccolithophores contributed nearly equal numbers from Days 11 to 15 ; the relative contribution of coccolithophores was somewhat higher than that of diatoms on Days 17 to 19 (Grossart et al. 2006a). There were also significant differences between the glacial and future mesocosms in the species composition of diatoms during the experiment (V. M. Jezequel unpubl. data).

Hydrolysis incubations (including hydrolysis rate measurements as well as determinations of bacterial cell numbers, protein production, and growth during the incubations) were initiated at 3 time points during the mesocosm experiment: (1) during the pre-bloom phase on mesocosm Day 0, (2) during the initial stage of exponential growth (early bloom development) on mesocosm Day 7, and (3) at late bloom development on mesocosm Day 15. Samples for analysis of changes in the composition of the bacterial community were collected from the same mesocosms (M1, M7) on mesocosm Days 0, 1 (pre-bloom phase), 6, 7 (early bloom) and 13, 15 and 20 (late bloom development, bloom peak, and post-bloom phases) to assess potential $\mathrm{pCO}_{2}$-related shifts in microbial community composition.

Measurements of hydrolysis rates. Enzymatic hydrolysis rates were measured using the method of Arnosti (1995, 1996). Polysaccharides obtained from Sigma or Fluka were labeled with fluoresceineamine (isomer II, Sigma) and characterized as described in Arnosti $(1995,2003)$. Equivalent monomer concentrations ( $3.5 \mathrm{nmol}$ monomer $\mathrm{ml}^{-1}$ mesocosm water, representing a ca. $20 \%$ increase in DOC) of each substrate were added to the samples to keep carbon additions consistent among experiments and to provide a measure for the hydrolysis that is independent of the rate calculation, as explained in detail in Arnosti (1995, 1996). In brief, given equivalent monomer concentrations of each added substrate, the relative rate at which 
a substrate is hydrolyzed to the monomer size class can be assessed via a direct comparison of chromatograms, as substrates hydrolyzed at similar rates should converge into the monomer size class on the same time scale.

Hydrolysis rates of chondroitin sulfate, fucoidan, laminarin, and xylan were measured by initiating duplicate incubations of each of these 4 substrates on mesocosm Days 0, 7 and 15 with water collected from parent mesocosms M1 and M7. These incubations are designated as deriving from the pre-bloom phase, early-bloom phase, and-late bloom phase. A third replicate sample for each substrate was treated with $10 \%$ formalin (final conc.) to act as a control. Concurrently, bacterial concentrations, size, fraction of attached bacteria, bacterial protein production (BPP), and bacterial cell multiplication (BCM) were measured in parallel sub-incubations in replicate vials to assess potential shifts in the bacterial population during the $6 \mathrm{~d}$ incubation period for the hydrolysis measurements (see next paragraph). All incubations were conducted in a temperature-constant cold room with simulated average in situ light and temperature (8.5 to $10^{\circ} \mathrm{C}$ ). The in situ daily average incident photon flux densities (between 400 and $700 \mathrm{~nm}$ ) varied between 90 and $560 \mu \mathrm{mol} \mathrm{m} \mathrm{m}^{-2} \mathrm{~s}^{-1}, 80 \%$ of which reached the water surface of the mesocosms (Schulz et al 2008). Our sub-incubations were exposed to approximately $150 \mu \mathrm{mol} \mathrm{m} \mathrm{m}^{-2} \mathrm{~s}^{-1}$ photosynthetically active radiation (PAR).

After an incubation period of $6 \mathrm{~d}$, samples $(1.5 \mathrm{ml})$ were filtered through a syringe filter (pore size $0.2 \mu \mathrm{m}$ ) and stored frozen until analysis. Samples were analyzed, and hydrolysis rates were calculated as described in Arnosti (1996, 2003). Frozen samples were thawed, diluted with milli-Q water, and analyzed on a gel permeation chromatography (GPC) system consisting of an autosampler with 2 gel columns (Sephadex G-50 and G-75, connected in series) whose outflow passed through a fluorescence detector with excitation and emission maxima set at 490 and $530 \mathrm{~nm}$, respectively. Hydrolysis was detected as changes with time in molecular weight of the substrates as they were hydrolyzed to products of lower molecular weight. These changes were resolved by the GPC system, and hydrolysis rates were calculated by knowing the size class of the hydrolysis products, the initial size spectrum of the polysaccharide, substrate concentration, and the elapsed time, as discussed at length in Arnosti $(1996,2003)$.

Bacterial numbers, production and growth during hydrolysis incubations. Every $2 \mathrm{~d}$ during the $6 \mathrm{~d}$ subincubations for hydrolysis measurements, the numbers of free and particle-associated bacteria were determined by filtering 1 to $5 \mathrm{ml}$ samples through black
Nucleopore membranes of pore size 0.2 and $5.0 \mu \mathrm{m}$, respectively. The filters were stained with 4',6diamidino-2-phenolindole (DAPI) and stored frozen at $-20^{\circ} \mathrm{C}$ until counted, as described by Grossart et al. (2006a). In parallel, rates of BPP were determined by incorporation of ${ }^{14}[\mathrm{C}]$-leucine $\left({ }^{14} \mathrm{C}\right.$-Leu, Simon \& Azam 1989) and BCM by incorporation of ${ }^{3}[\mathrm{H}]$-thymidine $\left({ }^{3} \mathrm{H}-\mathrm{TdR}\right.$, Fuhrman \& Azam 1982). Both parameters were simultaneously measured in the dual label approach (Chin-Leo \& Kirchman 1988), which has been described by Grossart et al. (2006a).

Isolation of DNA. Four-liter samples from the parent mesocosms (M1 and M7) were filtered through a Supor®-450 filter (0.45 $\mu \mathrm{m}$ pore size) (Gelman Sciences), and total environmental DNA was isolated from the filters following the method of Gordon \& Giovannoni (1996) with modifications as described by Fuller et al. (2003). In essence, this involved treatment with lysozyme at $37^{\circ} \mathrm{C}$ for $30 \mathrm{~min}$ followed by proteinase $\mathrm{K}$ digestion at $37^{\circ} \mathrm{C}$ for $15 \mathrm{~min}$ and another 60 min at $55^{\circ} \mathrm{C}$. Subsequently, the lysis mixture was transferred to microcentrifuge tubes and extracted twice with 1 vol chloroform/isopropanol (24:1). The DNA was precipitated (1 vol isopropanol; 0.4 vol $7.5 \mathrm{M}$ ammonium acetate), and the pellet was washed with $70 \%(\mathrm{v} / \mathrm{v})$ ethanol. The DNA pellet was resuspended in sterile, double-distilled water and stored at $-80^{\circ} \mathrm{C}$ until used for subsequent analyses.

Polymerase chain reaction (PCR) and denaturinggradient gel electrophoresis (DGGE). A nested PCR approach was applied to obtain sufficient PCR product for subsequent DGGE analyses as described by Mühling et al. (2008) and Dar et al. (2005). Aliquots of the PCR products obtained with the Bacteria primer-pair $9 \mathrm{bfm} / 1512 \mathrm{uR}$ were used as templates for reamplification with a nested bacterial primer set (341f-GC/518R). The PCR reaction was carried out in $50 \mu \mathrm{l}$ volumes and contained $2 \mathrm{mmol} \mathrm{l}^{-1} \mathrm{MgCl}_{2}, 200 \mu \mathrm{mol} \mathrm{l}^{-1} \mathrm{dNTPs}, 2.5 \mathrm{U}$ of Taq DNA polymerase (Promega) and $50 \mathrm{nmol}^{-1}$ of each of the primers. All PCRs used the same basic cycling protocol except for the annealing temperature (AT) and extension time (ET): following an initial denaturing step of $4 \mathrm{~min}$ at $96^{\circ} \mathrm{C}$, $30 \mathrm{PCR}$ cycles were performed $\left(96^{\circ} \mathrm{C}\right.$ for $60 \mathrm{~s}, \mathrm{AT}$ for $60 \mathrm{~s}, 74^{\circ} \mathrm{C}$ for $\left.\mathrm{ET}\right)$ followed by a final extension step at $74^{\circ} \mathrm{C}$ for $10 \mathrm{~min}$. The annealing temperature and extension time were $52^{\circ} \mathrm{C}$ and $56^{\circ} \mathrm{C}$ (AT) and $60 \mathrm{~s}$ and $20 \mathrm{~s} \mathrm{(ET)} \mathrm{for} \mathrm{primer}$ pairs $9 \mathrm{bfm} / 1512 \mathrm{uR}$ and $341 \mathrm{f}-\mathrm{GC} / 518 \mathrm{R}$, respectively. In all cases the PCR yielded only specific products, i.e. single bands as judged by electrophoresis of the PCR products on agarose gels.

The products from the re-PCRs were used for DGGE, which was based on Muyzer et al. (1993) and Dar et al. (2005). In essence, the PCR products were separated on an $8 \%(\mathrm{w} / \mathrm{v})$ polyacrylamide with urea 
and formamide as denaturants, producing a 40 to $60 \%$ gradient. Electrophoresis was performed in $1 \times$ TAE (Tris-acetate-EDTA) buffer at $60^{\circ} \mathrm{C}$ and at a constant voltage of $60 \mathrm{~V}$ for $18 \mathrm{~h}$. Subsequently, gels were stained in $1 \times$ SYBR Gold nucleic acid gel stain (Molecular Probes) for $45 \mathrm{~min}$ and rinsed in distilled water prior to image analysis on a Syngene GelDoc station. To test for reproducibility of the results, the DGGE analysis was repeated, starting with the (first) PCR amplification of 16S rRNA gene fragments from total environmental DNA isolated from the parent mesocosms.

Statistics. To test whether hydrolysis rates were significantly different between $\mathrm{pCO}_{2}$ treatments or/and phytoplankton bloom phases, we performed a univariate analysis of variance (ANOVA) using the software SPSS 17 . We tested whether enzymatic hydrolysis rates differed between (1) $\mathrm{pCO}_{2}$ treatments (glacial [M7] vs. future [M1]), (2) bloom phases (pre-bloom; early bloom; late bloom), and (3) whether the interaction between $\mathrm{CO}_{2}$ treatment and bloom phase was additionally significant.

To test for statistical differences between $\mathrm{pCO}_{2}$ treatments of bacterial parameters measured during the hydrolysis sub-incubations, we used paired $t$-test (2tailed) of the software PASW 17. Pairs were built by the bloom phase and incubation time. For selected parameters, a separate paired $t$-test for each bloom phase was possible. The Kolmogorov-Smirnow test was used to assess normal distribution. Additionally, correlations between these different bacterial parameters and hydrolysis rates were tested using the non-parametric Spearman's rank correlation.
DGGE profiles were converted into presence and absence binary matrices as well as quantitative matrices using the image analysis software Phoretix 2D (Nonlinear Dynamics). These matrices were explored using non-metric multidimensional scaling (MDS) based on Bray-Curtis similarities (Clarke \& Warwick 2001) using PRIMER v6 (www.primer-e.com), and results were depicted as a 2-dimensional MDS plot. The calculation of the similarity matrices was, in the case of the binary data, based on the simple-matching coefficient (Sokal \& Michener 1958), while the quantitative data were analyzed using Bray-Curtis similarities (Bray \& Curtis 1957) on square-root-transformed data. The results of the clustering approach were analyzed using the similarity profile routine (SIMPROF), which tests for the presence of patterns of clusters that could have arisen by chance (Clarke et al. 2008). Individual clusters of samples that were shown by the SIMPROF test to be different from each other are indicated in the MDS plots.

\section{RESULTS}

\section{Enzyme activities}

Enzyme activities differed markedly by substrate (Fig. 1). Chondroitin hydrolysis varied between 2 and $>40 \mathrm{nmol}$ monomer $\mathrm{l}^{-1} \mathrm{~h}^{-1}$ over the course of the mesocosm bloom. Fucoidan hydrolysis was measurable only in the glacial mesocosm, at trace levels in the earlybloom phase and at high levels in the late-bloom phase (Fig. 1). Laminarin and xylan hydrolysis rates were
Fig. 1. Extracellular enzymatic hydrolysis of (a) chondroitin sulfate, (b) fucoidan, (c) laminarin and (d) xylan in duplicate incubations of water from the mesocosm with glacial $\mathrm{pCO}_{2}$ (striped bars; white bars) and the mesocosm with future $\mathrm{pCO}_{2}$ (gray bars; black bars) for incubations initiated during the pre-bloom (Day 0), the early-bloom (Day 7), and the late-bloom phases (Day 15). Note the difference in $y$-axis scales among substrates
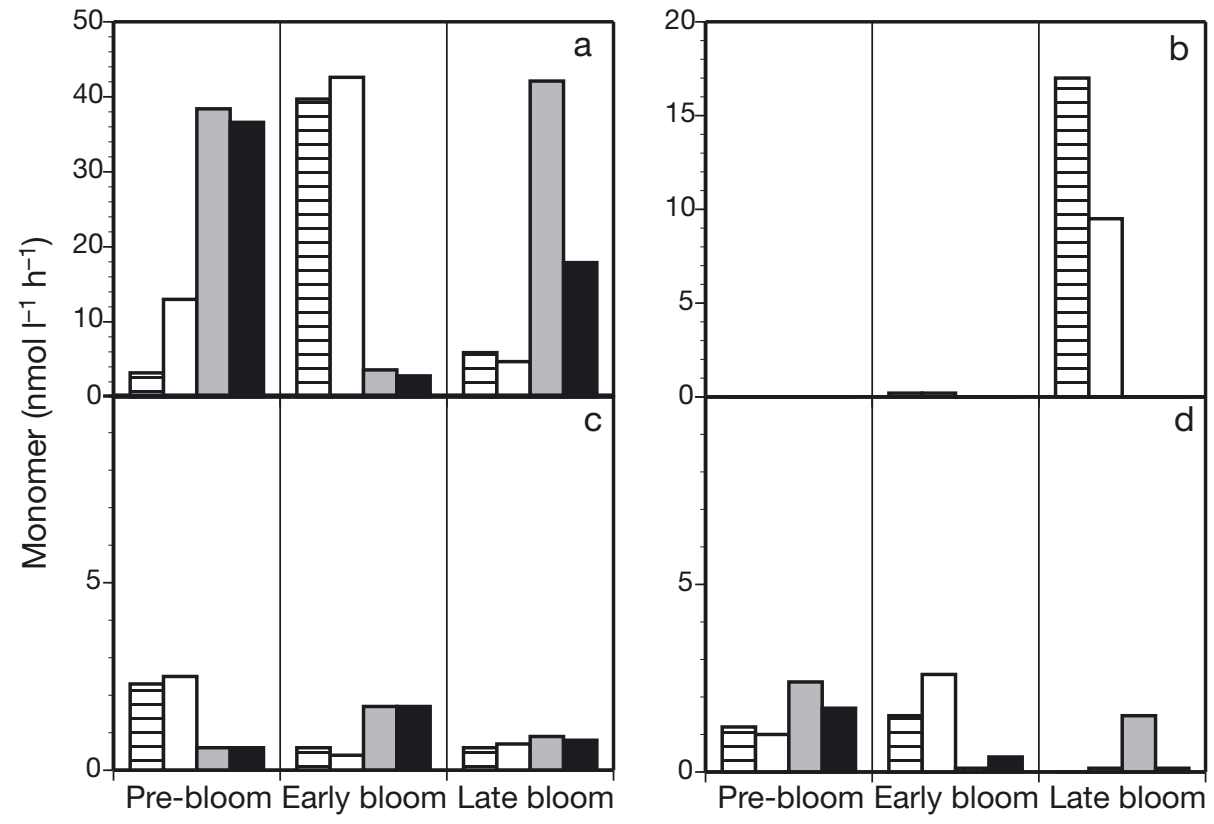
generally $<3$ nmol monomer $\mathrm{l}^{-1} \mathrm{~h}^{-1}$ throughout the course of the mesocosm bloom. Activities in parallel incubations at each time point were, in most cases, very similar.

Temporal variability of chondroitin hydrolysis was high, with activity in the glacial mesocosm increasing from ca. 3 to $13 \mathrm{nmol}$ monomer $\mathrm{l}^{-1} \mathrm{~h}^{-1}$ to ca. $40 \mathrm{nmol}$ monomer $\mathrm{l}^{-1} \mathrm{~h}^{-1}$ between pre-bloom and early-bloom phases, and then returning to ca. $5 \mathrm{nmol}$ monomer $\mathrm{l}^{-1}$ $\mathrm{h}^{-1}$ in the late-bloom phase (Fig. 1a). The opposite pattern was evident in the future mesocosm, where hydrolysis rates decreased from ca. $40 \mathrm{nmol}$ monomer $\mathrm{l}^{-1} \mathrm{~h}^{-1}$ in the pre-bloom phase to ca. $5 \mathrm{nmol}$ monomer $\mathrm{l}^{-1} \mathrm{~h}^{-1}$ in the early-bloom phase, and returned to 18 to $42 \mathrm{nmol}$ monomer $\mathrm{l}^{-1} \mathrm{~h}^{-1}$ in the late-bloom phase. Fucoidanase activity (Fig. 1b) was not detectable at any time point in the future mesocosm, but a trace of activity was detected in the glacial mesocosm in the early-bloom phase, and activity was high (9.5 to 17 nmol monomer $\mathrm{l}^{-1} \mathrm{~h}^{-1}$ ) in the late-bloom phase. Laminarinase activity (Fig. 1c) was relatively invariant in the future mesocosm, and showed a declining trend in the glacial mesocosm. Xylanase activity (Fig. 1d) in the pre-bloom phase was higher than during the earlyand late-bloom phases in the future mesocosm. In the glacial mesocosm, xylanase was also higher in the pre-

Table 1. Results of ANOVA to examine the effect of $\mathrm{pCO}_{2}$ and bloom phase in determining the rates of enzyme hydrolysis. ns $=$ not significant

\begin{tabular}{|c|c|c|c|}
\hline Source & df & $F$ & $\mathrm{p}$ \\
\hline \multicolumn{4}{|l|}{ Chondroitin sulfate } \\
\hline Model & 5 & 10.295 & 0.007 \\
\hline Treatment $\left(\mathrm{pCO}_{2}\right)$ & 1 & 1.509 & $\mathrm{~ns}$ \\
\hline Bloom phase & 2 & 0.548 & $\mathrm{~ns}$ \\
\hline \multicolumn{4}{|l|}{ Interaction (treatment $\times$} \\
\hline \multicolumn{4}{|l|}{ Laminarin } \\
\hline Corrected model & 5 & 106.665 & $<0.0001$ \\
\hline Treatment $\left(\mathrm{pCO}_{2}\right)$ & 1 & 3.970 & ns \\
\hline Bloom phase & 2 & 49.109 & $<0.0001$ \\
\hline $\begin{array}{l}\text { Interaction (treatment } \times \\
\text { bloom phase) }\end{array}$ & 2 & 215.569 & $<0.0001$ \\
\hline \multicolumn{4}{|l|}{ Xylan } \\
\hline Corrected model & 5 & 4.735 & 0.042 \\
\hline Treatment $\left(\mathrm{pCO}_{2}\right)$ & 1 & 0.002 & ns \\
\hline Bloom phase & 2 & 4.294 & $\mathrm{~ns}$ \\
\hline $\begin{array}{l}\text { Interaction (treatment } \times \\
\text { bloom phase) }\end{array}$ & 2 & 7.543 & 0.023 \\
\hline \multicolumn{4}{|l|}{ Fucoidan } \\
\hline Corrected model & 5 & 12.634 & 0.004 \\
\hline Treatment $\left(\mathrm{pCO}_{2}\right)$ & 1 & 13.099 & 0.011 \\
\hline Bloom phase & 2 & 12.523 & 0.007 \\
\hline \multicolumn{4}{|l|}{ Interaction (treatment $\times$} \\
\hline bloom phase) & 2 & 12.523 & 0.007 \\
\hline
\end{tabular}

bloom and early-bloom phases than in the late-bloom phase. No hydrolysis was detected in the formalinkilled controls.

The ANOVA testing for differences between $\mathrm{pCO}_{2}$ treatments and bloom phases confirmed different patterns of enzyme activities for all 4 substrates (Table 1). The only enzyme activity with a directly measurable difference between the $2 \mathrm{pCO}_{2}$ treatments was fucoidanase, which showed significantly higher activities in the glacial mesocosm than in the future mesocosm. Fucoidanase also showed significant differences between bloom phases, with the highest activity in the late-bloom phase in the glacial mesocosm. Significant differences in laminarin hydrolysis rates could be attributed to bloom phase alone, with the highest activities in the glacial mesocosm in the pre-bloom phase and in the future mesocosm in the early-bloom phase. For all 4 enzyme activities, the interaction between $\mathrm{pCO}_{2}$ treatments and bloom phases was statistically significant, indicating diverging $\mathrm{pCO}_{2}$ effects on the enzyme activities in the different bloom phases.

\section{Bacterial numbers, production and growth measured concurrently with hydrolysis incubations}

Hydrolysis rate determinations with high-molecularweight substrates required relatively long (6 d) incubations because activity is detected as changes in molecular weight of the total added substrate. For this reason, bacterial numbers, production, and growth rates were monitored in sub-incubations concurrently with the measurement of enzymatic hydrolysis rates. Concurrent measurements from parallel vials were used rather than measuring all parameters from the same vial because of technical constraints (avoiding radioactive contamination of chromatographic equipment used to analyze enzyme activity samples; potential interference of fluoresceinamine with DAPI staining). The microbial parameters measured in the parallel vials were compared to microbial dynamics in the parent mesocosms (data from Grossart et al. 2006a) to determine the extent to which microbial communities may have diverged in sub-incubations compared with the parent mesocosms.

Bacterial abundance and size changed only modestly over the time course of each sub-incubation (starting at mesocosm Days 0, 7 and 15, corresponding to the pre-bloom, early-bloom, and late-bloom phases; see Table 2) and did not differ significantly between $\mathrm{pCO}_{2}$ treatments. Bacterial abundances in the subincubations generally reflected those in the parent mesocosms, where bacterial numbers increased from Day 0 to Day 8, before dropping back to close to initial 
Table 2. Cell counts $\left(10^{6} \mathrm{ml}^{-1}\right.$, with SD), bacterial production (BPP, $\left.\mu \mathrm{g} \mathrm{C} \mathrm{l}^{-1} \mathrm{~h}^{-1}\right)$, and bacterial cell multiplication (BCM, $10^{6}$ cells $\mathrm{ml}^{-1} \mathrm{~h}^{-1}$ ) during $6 \mathrm{~d}$ incubations for hydrolysis measurements from the mesocosms with glacial and future levels of $\mathrm{pCO}_{2}$

\begin{tabular}{|c|c|c|c|c|c|c|}
\hline \multirow{2}{*}{$\begin{array}{l}\text { Sub-incubation } \\
\text { day }\end{array}$} & \multicolumn{3}{|c|}{-Glacial mesocosm day } & \multicolumn{3}{|c|}{ - Future mesocosm day } \\
\hline & 0 & 7 & 15 & 0 & 7 & 15 \\
\hline \multicolumn{7}{|l|}{ Cell count $( \pm \mathrm{SD})$} \\
\hline 0 & $1.49(0.21)$ & $1.65(0.11)$ & $0.98(0.11)$ & $1.44(0.27)$ & $1.58(0.12)$ & $0.87(0.11)$ \\
\hline 2 & $1.66(0.19)$ & $1.89(0.21)$ & $1.16(0.15)$ & $1.65(0.25)$ & $1.94(0.18)$ & $1.07(0.10)$ \\
\hline 4 & $1.81(0.21)$ & $2.29(0.17)$ & $1.39(0.13)$ & $1.87(0.20)$ & $2.41(0.21)$ & $1.00(0.09)$ \\
\hline 6 & $1.66(0.09)$ & $1.51(0.11)$ & $1.40(0.10)$ & $1.66(0.10)$ & $1.54(0.13)$ & $0.94(0.10)$ \\
\hline \multicolumn{7}{|c|}{ Attached bacteria (\%) } \\
\hline 0 & 8 & 13 & 4 & 8 & 21 & 7 \\
\hline 2 & 8 & 13 & 7 & 9 & 20 & 12 \\
\hline 4 & 15 & 12 & 9 & 13 & 19 & 15 \\
\hline 6 & 24 & 18 & 9 & 23 & 31 & 21 \\
\hline \multicolumn{7}{|l|}{ BPP } \\
\hline 0 & 9.4 & 3.0 & 8.4 & 1.7 & 3.2 & 4.0 \\
\hline 2 & 9.8 & 2.0 & 13.9 & 9.9 & 9.1 & 9.0 \\
\hline 4 & 11.6 & 6.0 & 8.3 & 6.3 & 2.4 & 2.0 \\
\hline 6 & 4.0 & 1.9 & 4.8 & 2.9 & 4.0 & 1.8 \\
\hline \multicolumn{7}{|l|}{ BCM } \\
\hline 0 & 0.05 & 0.40 & 0.30 & 0.02 & 0.17 & 0.11 \\
\hline 2 & 1.29 & 0.13 & 1.12 & 0.50 & 0.54 & 0.69 \\
\hline 4 & 1.19 & 0.23 & 0.97 & 0.33 & 0.09 & 0.28 \\
\hline 6 & 0.43 & 0.03 & 0.30 & 0.11 & 0.23 & 0.30 \\
\hline
\end{tabular}

numbers from Days 12 to 18 (Grossart et al. 2006a). The increase in the fraction of attached bacteria throughout the sub-incubations was likewise similar to the pattern observed in the parent mesocosms. Significantly higher fractions of attached bacteria were found in the future treatment compared to the glacial treatment, for all bloom phases together (paired $t$-test, $t=$ 3.76 , df $=11, p=0.003)$, and in the early- and latebloom phases when considered separately (paired $t$ test, $\mathrm{df}=3$; Day 7: $t=6.617, \mathrm{p}=0.007$; Day 15: $t=3.773$, $\mathrm{p}=0.033$ ). The volume of attached bacteria (as a percentage of total bacteria) was likewise significantly higher in the future treatment than in the glacial treatment, for all bloom phases together (paired $t$-test, $t=$ 3.894, df $=11, p=0.003$ ), and in the early- and latebloom phases when considered separately (paired $t$ test, df $=3$; Day 7: $t=20.865, \mathrm{p}<0.0001$; Day 15: $t=$ 4.232, $\mathrm{p}=0.024)$.

BPP and BCM varied over the time course of the $6 \mathrm{~d}$ incubations (Table 2), but final rates after $6 \mathrm{~d}$ in the sub-incubations were similar to those in the parent mesocosms, and patterns of variation were similar for BPP and BCM. Sub-incubations started in the earlyand late-bloom phases reflected BCM and BPP in the parent mesocosms very well, whereas values measured in incubations started at the pre-bloom phase were higher than in their respective parent mesocosms. Because the pre-bloom phase represented the start of the mesocosm experiment, potential variability caused by the perturbations of the initial set-up was still high. Given the overall variability in results, however, these differences were relatively minor. The range of variability of BPP and BCM in the sub-incubations was similar to that of the parent mesocosm $(2$ to $12 \mu \mathrm{C} \mathrm{Cl}^{-1} \mathrm{~h}^{-1}$ for BPP, 0.1 to $0.9 \times 10^{6}$ cells $\mathrm{ml}^{-1} \mathrm{~h}^{-1}$ for BCM; Grossart et al. 2006a). While BPP in subincubations did not significantly differ between $\mathrm{pCO}_{2}$ treatments, BCM was significantly lower in the future treatment than in the glacial treatment when all bloom phases were pooled (paired $t$-test, $t=-2.304$, $\mathrm{df}=11, \mathrm{p}=0.042$ ). However, individual phases showed no significant differences in BCM between glacial and future treatments. These findings are consistent with the parent mesocosm investigations where the number of attached bacteria, BPP, BCM and growth rate also differed significantly with $\mathrm{pCO}_{2}$ (Grossart et al. 2006a).

All parameters were also examined for correlations with each other. Whereas several bacterial parameters, e.g. bacterial size with bacterial number, BPP with $\mathrm{BCM}$, and BPP with growth rate, were correlated with each other (Table 3), none of the bacterial parameters correlated with any of the measured enzyme activities (Spearman rank correlation). This suggests that activities of the selected enzymes were more dependent on specific members of the bacterial community, or on DOM composition, than on the abundance and average activity of the total community. 
Table 3. Significant results of Spearman rank correlations between the bacterial parameters (bacterial concentration, cell size, bacterial cell multiplication (BCM), bacterial production (BPP) and growth rate $(\mu)$ ) each of attached, free and total bacteria during hydrolysis incubations. No significant results were found for a Spearman rank correlation between these bacterial parameters and the enzymatic hydrolysis rates

\begin{tabular}{|c|c|c|}
\hline Parameter & Spearman's rho & $\mathrm{p}$ \\
\hline $\begin{array}{l}\text { Bacterial size }+ \\
\text { total number of bacteria }\end{array}$ & 0.210 & 0.004 \\
\hline $\begin{array}{l}\text { Attached bacterial size }+ \\
\text { total number of bacteria }\end{array}$ & 0.802 & $<0.0001$ \\
\hline $\mathrm{BPP}+\mathrm{BCM}$ & 0.700 & $<0.0001$ \\
\hline $\mathrm{BPP}+\mu$ & 0.606 & 0.002 \\
\hline
\end{tabular}

\section{Microbial community composition}

Multivariate statistical analysis of the DGGE profiles revealed that-between the early- and late-bloom phases (samples collected on mesocosm Days 7 and 13, respectively) - the communities of both parent mesocosms underwent a distinct compositional shift. This is indicated in Fig. 2a,c. Relative distances between samples reflect inter-sample similarities, with samples close together being similar in terms of their bacterial composition (based on the DGGE profiles). The maximum similarities at which a separation into different groups could not have arisen by chance (tested using the SIMPROF analysis) are indicated for each of the MDS plots. These ovals correspond to the $70 \%$ similarity clusters (dashed lines), except in those cases where samples are grouped by dotted lines, i.e. individual clusters of samples grouped by dashed/dotted lines are shown by the SIMPROF test to be different to each other. This finding was independent of the manner of analysis of the DGGE profiles, as presence/absence data (Fig. 2a) or as quantitative data (Fig. 2c). Whereas during the pre-bloom phase the microbial communities of both the glacial and future mesocosms were similar, they diverged appreciably after Day 7 (the early-bloom phase). In both mesocosms, communities became more
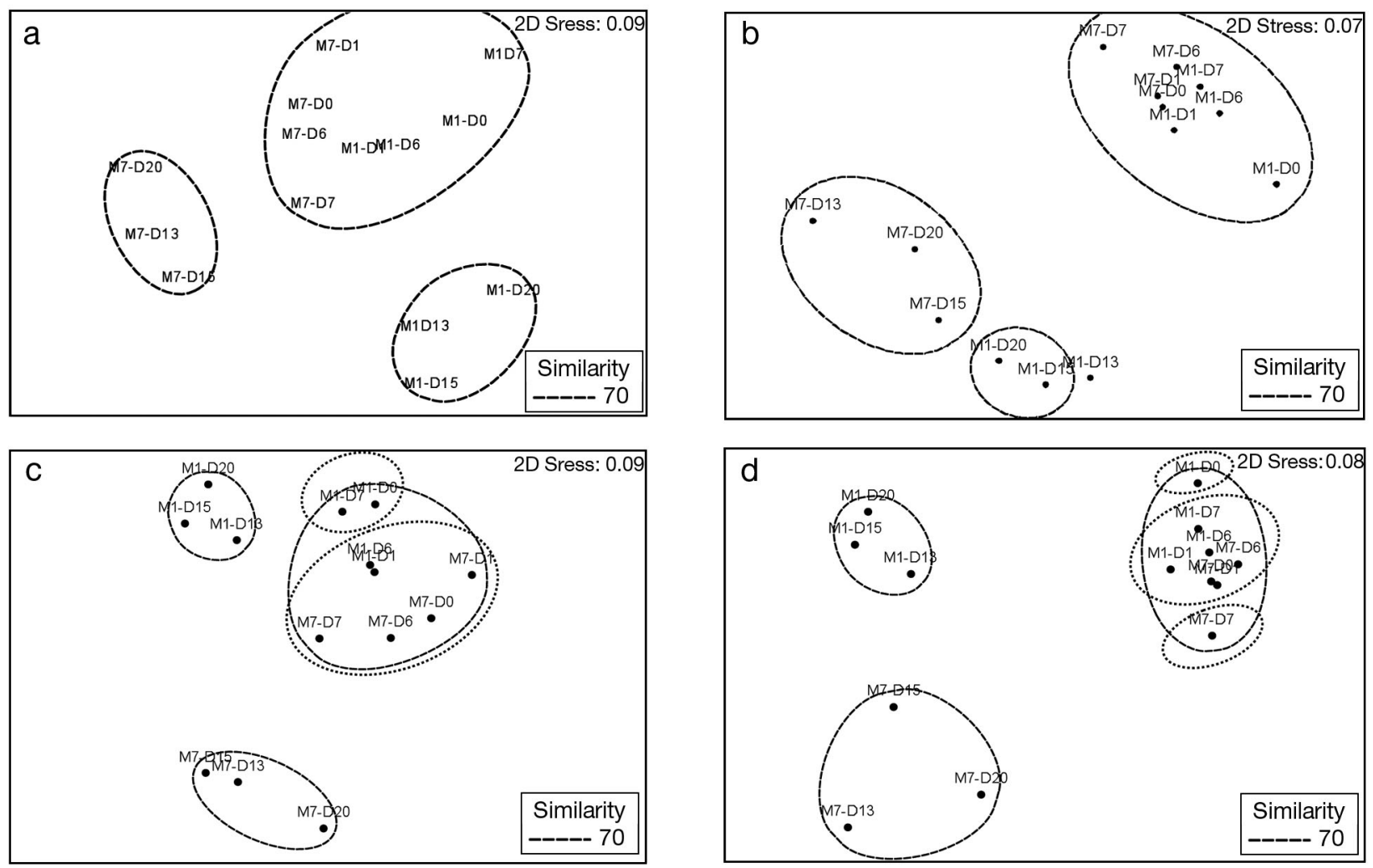

Fig. 2. Non-metric multidimensional scaling (MDS) ordination plots of bacterial diversity. Plots were derived from the denaturing-gradient gel electrophoresis (DGGE) profiles of each mesocosm sample. Individual samples within each plot are identified by number of the parent mesocosm (M1 = future mesocosm, M7 = glacial mesocosm) and day of sampling. This analysis was independently replicated (see 'Materials and methods') and replicates were analyzed as binary data (presence/absence; a,c) and as quantitative data (b,d). Stress values (Kruskal's stress formula 1) are $\leq 0.1$, indicating acceptable representations of multivariate relationships in this 2-dimensional plot. Relative distances between samples reflect inter-sample similarities, with samples close together being similar in terms of their bacterial composition (based on the DGGE profiles). For each MDS plot, maximum similarities at which a separation into different groups could not have arisen by chance is indicated (see 'Results' for details). D: day 
distinct from the pre-bloom community in the latebloom phase (from ca. Day 13). Each community remained relatively unchanged thereafter (late-bloom to post-bloom phase, Days 13 to 20).

To verify this evidence of temporally increasing differences between the composition of the populations in the glacial and future mesocosms, this analysis was repeated, starting with PCR amplification of the 16S rRNA gene fragments (i.e. PCR with primer pair $9 \mathrm{bfm} / 1512 \mathrm{uR}$ ) using the same preparation of environmental DNA that was used as the DNA template in the first analysis (see 'Materials and methods'). The subsequent analyses of the DGGE profiles confirmed that the observed changes in diversity were indeed reproducible, again independently of whether analyzed as presence/absence data (Fig. 2b) or as quantitative (Fig. 2d) data.

\section{DISCUSSION}

\section{Enzymatic hydrolysis of complex polysaccharides}

Measuring the activities of extracellular enzymes that initiate microbial remineralization of high-molecular-weight organic matter provides information about the initial step in carbon cycling. Although carbohydrates, as a class, constitute a significant fraction of marine DOM (e.g. Benner et al. 1992), determining the chemical structure and concentration of specific dissolved combined carbohydrates in seawater is currently beyond the technical capabilities of the marine scientific community as a whole. However, the polysaccharide substrates used in these experiments are present in marine environments, and measuring their rates of hydrolysis provides information that otherwise cannot be obtained.

We assume that measurements of enzymatic activities in the sub-incubations represent, to a reasonable degree, the hydrolytic potential of the populations of the parent mesocosms, because temporal developments of bulk bacterial community parameters (cell numbers, $\mathrm{BPP}$, and $\mathrm{BCM}$ ) in hydrolysis incubations mirrored those of the parent mesocosms from which they were derived. The data clearly show that these populations have the potential to degrade specific high-molecular-weight polysaccharides. This ability may be the result of selective growth of 1 fraction of the population, or of induction of a suite of enzymes (selective gene expression) within a stable population, or a combination of both processes. The hydrolysis rates consequently express the potential metabolic capabilities of the population.

Previous determinations of enzymatic hydrolysis of complex polysaccharides in seawater were, with 1 exception (Murray et al. 2007), all 'snapshot' measurements taken at different pelagic locations in the Atlantic, Pacific and Arctic Oceans, and the Gulf of Mexico (e.g. Arnosti 2000, 2008, Arnosti et al. 2005, Steen et al. 2008). In comparison to these earlier measurements, rates of chondroitin hydrolysis and maximal rates of fucoidan hydrolysis were high in the mesocosm experiments, whereas laminarinase and xylanase activities were quite low. Within both mesocosms, temporal variability of chondroitinase activity was high, and there were comparatively large differences between replicate vials (Fig. 1), perhaps a consequence of variable sampling efficiency of particle- or microaggregate-associated bacteria. The development of high levels of fucoidanase activity during the latebloom phase of the glacial mesocosm was also notable because fucoidanase activity is rarely detected in pelagic samples (see references above) although Fucus sp. is a common macroalga and high fucoidanase activity is commonly measured in marine sediments (e.g. Arnosti 2000, 2008).

Laminarinase activity appears to be ubiquitous in the water column, having been detected at all sites measured to date (see references above). The ubiquity of laminarinase activity, however, may be related to the fact that laminarin, the target of laminarinase enzymes, is a storage polysaccharide of diatoms, and is produced in large quantities (an estimated 5 to 15 billion metric tons annually; Alderkamp et al. 2007) in the ocean. However, there does not appear to be a direct connection between the abundance of diatoms and laminarinase activity because hydrolysis rates of laminarin during a diatom bloom were similar to those measured during a bloom of Phaeocystis spp. (Murray et al. 2007). Laminarinase activity has been found in diverse marine phylogenetic groups (Alderkamp et al. 2007) and may be more widespread among heterotrophic microbes than are other polysaccharide-hydrolyzing enzymes. Xylanase activities in our mesocosms, like laminarinase activities, were on the lower end of those observed in other locations (see references above). The decline in xylanase activity with time may be linked to changes in specific microbial phylotypes, as was observed previously (Murray et al. 2007).

Low-molecular-weight substrate proxies (MUF- $\alpha$ and $\beta$-glucose) were used with water from the parent mesocosms to assess activities of exo-acting enzymes that hydrolyze glucose-containing carbohydrates (Grossart et al 2006a). Such measurements capture enzyme activity over short timescales (typical experimental incubation times of hours), and thus reflect a 'snapshot' view of enzyme potential at the time of sampling. The enzymes whose activities are measured with MUF substrates are distinct from those measured with fluorescently labeled polysaccharides, because 
only exo-acting (terminal-unit-cleaving) enzymes can hydrolyze MUF substrates, whereas polysaccharides can also be cleaved mid-chain by endo-acting enzymes.

In the future mesocosm, hydrolysis rates of MUF- $\alpha$ glucose were, on average, higher than in the glacial mesocosm, especially in the early- and late-bloom phases (Grossart et al. 2006a). For MUF- $\beta$-glucose, only 1 timepoint in the future mesocosm showed an elevated hydrolysis rate compared to the glacial mesocosm. In the glacial mesocosm, hydrolysis rates of MUF- $\alpha$ - and MUF- $\beta$-glucose showed no temporal trends and were relatively invariant throughout all phases of bloom development. There was no statistically significant relationship between $\mathrm{pCO}_{2}$ and hydrolytic activity for either MUF- $\alpha$ - or $\beta$-glucose (Grossart et al. 2006a).

The picture from the short timescale MUF-glucose substrate proxies thus differs from the information obtained by measuring hydrolysis of specific complex polysaccharides over longer timescales. In particular, the comparatively low and constant enzymatic activity, especially in the glacial mesocosm, is clearly different from the activities of the endo-acting enzymes shown in Fig. 1. Because heterotrophic microbial communities use a range of exo- and endo-acting enzymes to hydrolyze specific substrates, and because responses to polysaccharide substrates can include induction and growth, development of a wider range of experimental approaches to measure the activities of specific enzymes should be a high priority. Current methods lack the sensitivity to reveal the full picture of the variations and nuances that are involved in microbial degradation of high-molecular-weight substrates.

\section{Impact of $\mathrm{pCO}_{2}$ conditions on interactions within the microbial loop}

The objective of this experiment was to assess how a change in oceanic $\mathrm{pCO}_{2}$ might affect prokaryotic and eukaryotic organisms. Such effects could occur at multiple levels - direct effects of pH on enzyme kinetics, a cellular response leading to a difference in extracellular enzyme production, and/or changes in the composition of the prokaryotic heterotrophic community. This complexity may partly explain the diversity of results from studies on the likely effects of changing $\mathrm{pCO}_{2}$ on marine organisms and processes (see Liu et al. 2010 and Joint et al. 2011 for recent summaries). The PeECE I investigation, for example, found little to no effect of $\mathrm{pCO}_{2}$ treatment on the composition or numbers of phytoplankton species, and found no net increases in bacterial populations in mesocosms with glacial, current or future $\mathrm{pCO}_{2}$ (Rochelle-Newall et al 2004).
These observations are different from those in the current study, and they may relate, in part, to the quantity and molar ratio of added nutrients in PeECE I and PeECE II, as noted by Engel et al (2008). During PeECE III, no $\mathrm{pCO}_{2}$ treatment-related effects were observed for bacterial abundance, activity, or affinity for glucose, although bacterial production of freeliving and attached bacteria, as well as the bacterial community composition, did differ between treatments (Allgaier et al. 2008, Tanaka et al. 2008). The diverging results from these 3 - essentially very similar - mesocosm studies imply that complex interactions within the whole microbial loop, rather than a simple linear response of microbes to altered carbonate chemistry, may be expected.

In order to examine concurrently the temporal development of phytoplankton, bacterial numbers, and enzyme activities during the pre-bloom, early-bloom, and late-bloom phases, all of these components of the microbial loop were plotted together (Fig. 3). Bacterial counts are shown in the central panel (data re-plotted from Grossart et al 2006a), with vertical lines on the central panel corresponding to the pre-bloom, earlybloom and late-bloom phases. The number and species of phytoplankton corresponding to the pre-bloom, early-bloom and late-bloom phases are plotted below the main panel (data re-plotted from Engel et al. 2008). The enzyme activities corresponding to these bloom phases are presented as fractions of total activity, shown at the top of the figure. The parent mesocosms clearly showed a shift in the composition of the microbial community at the end of the early-bloom phase (Fig. 2), represented by the gray shading of the main panel in Fig. 3.

The species and number of phytoplankton differed between the mesocosms and differed with bloom phase (Fig. 3). In addition, differences in particle dynamics (e.g. in size spectra and abundance of particles detected with a Coulter counter) between the glacial and future mesocosms became evident in the early-bloom phase, after Day 5 (Engel et al. 2008). Bacterial numbers increased and then showed a divergence between mesocosms starting on Day 8. The rapid decline in cell counts corresponds to a time of maximal viral abundance (Grossart et al. 2006a), and thus may have been due to the effects of viruses or grazers. The late-bloom phase of the mesocosm (shaded in gray, Fig. 3) also coincides with the establishment of divergent microbial communities in the glacial and future mesocosms, which became increasingly distinct from each other and from the initial microbial community (Fig. 2). The distinct differences in patterns of enzyme activities (top part of Fig. 3) also accompanied the differing phases of the phytoplankton bloom. 


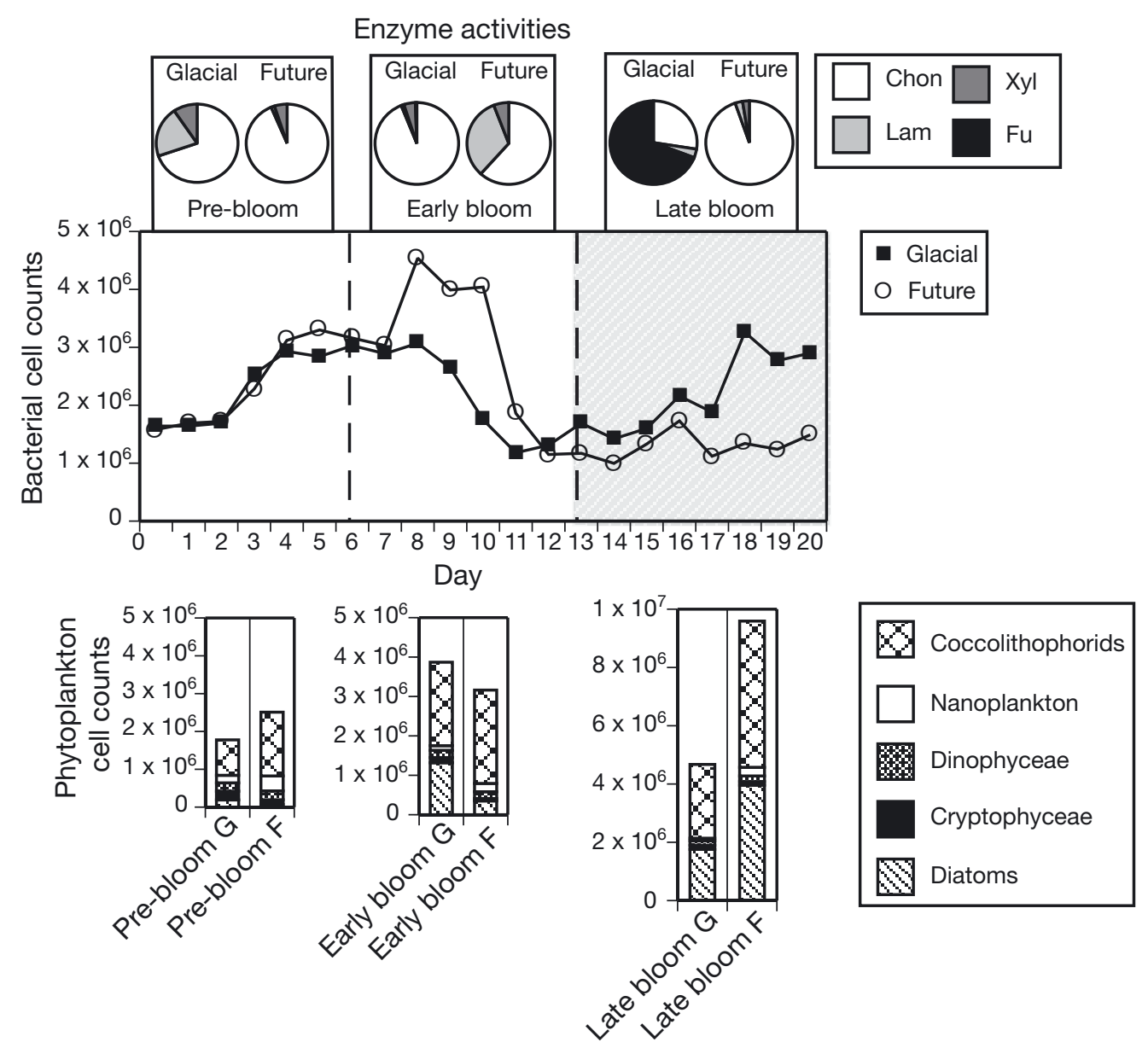

Fig. 3. Temporal development of components of the microbial loop showing bacterial cell counts (data from Grossart et al. 2006a) and phytoplankton cell counts and species composition (data from Engel et al. (2008), where counts on Days 3 to 5 are pre-bloom, those on Days 7 to 13 are early bloom, and counts on Days 15 to 19 are from the late-bloom phase. Extracellular enzyme activities are plotted as a fraction of summed activities during the pre-bloom, early-bloom and late-bloom phases. Chon $=$ chondroitin sulfate, Lam = laminarin, $\mathrm{Xyl}=$ xylan, Fu = fucoidan. Vertical lines divide the pre-bloom, early-bloom and late-bloom phases in the bacterial cell count panel. Gray shading of bacterial cell counts during the late-bloom phase indicates that the composition of the bacterial communities diverged from earlier phases; there were also increasing differences between glacial (G) and future (F) mesocosm communities (see Fig. 2)

Given these patterns of concurrent, multifaceted changes in phytoplankton and bacterial populations, the explanation for changes in patterns of enzyme activities is complex and not due to a single factor. Statistical analyses demonstrated that all 4 enzyme activities were different between mesocosms and were related to both $\mathrm{pCO}_{2}$ and bloom phase (Table 1). We interpret this to indicate a response to coupled microbial loop interactions, partially portrayed in Fig. 3, that can encompass the phytoplankton, bacterial and viral response to growth. The DGGE analyses (supported by a SIMPROF analysis of the differences between clusters of samples) clearly show that the bacterial community was changing with time and diverging between mesocosms; enzyme activity measurements show that the function of the bacterial community was also shifting.
A likely avenue for the coupling of phytoplankton and bacterial populations is through bacterial growth substrates, in particular exudation products of growing phytoplankton. Because phytoplankton species, growth stage, and environmental conditions have been found to affect the release of DOM, and its availability to heterotrophic bacteria (Myklestad 1995, Nagata 2000, Carlson 2002), the diverging development of autotrophs in the glacial and future mesocosms may well have yielded compositionally different DOM. Although concentrations of DOC were relatively constant through time in all mesocosms (Grossart et al. 2006a), the relative concentrations of dissolved free and combined amino acids in DOM varied during this experiment in such a manner that the composition of the bulk DOM must have changed with time (Grossart 
et al. 2006a). Moreover, the timing of the bloom, and the changes in species composition, differed somewhat between mesocosms, probably also affecting DOM composition.

Other investigations have demonstrated that the source and nature of DOM can lead to changes in the heterotrophic bacterioplankton community that utilizes it (Cottrell \& Kirchman 2000, Carlson et al. 2009). Bacterial community structure has also been found to depend on species, growth, and the physiological state of specific phytoplankton (Grossart et al. 2005). In the current experiment, differences between parent mesocosms in the concentration of attached bacteria and in $\mathrm{BPP}$, especially in the later phases of this experiment, were assumed to be a response to variations in the composition of the phytoplankton community and in exudation products (Grossart et al. 2006a). Another driving force for change in the microbial community could have been the activities of viruses, which may account for the rapid decline in total bacterial numbers after Day 8 (Grossart et al. 2006a). Selective cropping of the heterotrophic population could also lead to changes in the rates and types of enzyme activities because marine heterotrophic bacteria differ in the kinds of enzymes they express (Martinez et al. 1996).

A direct $\mathrm{pCO}_{2}$ effect on enzyme activities due to $\mathrm{pH}$ differences in our mesocosms is not likely, although a $\mathrm{pH}$ effect has been reported in a recent experimental investigation in which $\mathrm{pH}$ was manipulated directly by the addition of maleic acid/TRIS to seawater (Yamada \& Suzumura 2010) and in experiments where $\mathrm{pH}$ was decreased by $\mathrm{CO}_{2}$ aeration or the addition of acid (Piontek et al. 2010). In our investigation, $\mathrm{pH}$ did not change significantly over time in the glacial mesocosm, whereas hydrolysis of chondroitin, xylan and fucoidan did. A pH effect could, in theory, have been masked by differences in the quantity or nature of enzymes produced by the bacterial community, or in the turnover time of these enzymes, but such effects cannot be detected with the experimental methods used here.

\section{CONCLUSION}

The complex connections between $\mathrm{pCO}_{2}$, phytoplankton, heterotrophic bacteria and extracellular enzyme activities may best be envisioned as a network, rather than as a linear set of components. Changes in phytoplankton populations, in response to changed $\mathrm{pCO}_{2}$, probably yielded qualitatively different dissolved substrates for heterotrophic microbes (see Allgaier et al. 2008). The enzyme complement needed to access these different resources changed in response to changing DOM. In the early phase of the mesocosm experiment, these enzymatic responses might have resulted from changes in the extent of gene expression because heterotrophic communities were initially similar between mesocosms (Fig. 2). The differences in hydrolysis profiles in the late-bloom stage, as exemplified by the rapid hydrolysis of fucoidan in the glacial mesocosm (Fig. 1), probably reflect the enzymatic capabilities of compositionally different communities in the 2 mesocosms. Both mechanisms-different levels of gene expression, as well as different physiological capabilities - may therefore underlie the enzymatic responses observed in these experiments. The response of the marine microbial community to changed carbonate chemistry is multi-faceted and frequently indirect, complicating efforts to predict the impacts of ocean acidification on the microbial loop and the cycling of organic matter. Determining the relative contributions of genetic regulation and population shifts to this response, at both community and cellular levels, will be a major challenge for future research efforts.

Acknowledgements. We thank U. Riebesell and his team for organizing the mesocosm study, the University of Bergen Large Scale Facilities for hosting us, and all the participants who made this challenging project a success. We also thank R. Griffiths (Centre for Ecology and Hydrology, Oxford) for scanning the DGGE gels using the Phoretix 2D image analysis software. Three reviewers provided thoughtful and detailed comments that helped us considerably to improve the manuscript. Support for this project was provided by NSF (OCE-0848703 to C.A.; OCE-0926711 to U.P.), the Alfred Wegener Institute (C.A. and U.P.), the Hanse-Wissenschafts Kolleg (C.A.), the BMBF-BIOACID project (FKZ 03F0608E; to H.P.G.) and from the EU - project Microbial Marine Communities Diversity: from Culture to Function (MIRACLE) (EVK3-CT-2002-00087 to I.J.).

\section{LITERATURE CITED}

Alderkamp AC, van Rijssel M, Bolhuis H (2007) Characterization of marine bacteria and the activity of their enzyme systems involved in degradation of the algal storage glucan laminarin. FEMS Microbiol Ecol 59:108-117

Allgaier M, Vogt M, Thyrhaug R, Riebesell U, Grossart HP (2008) Coupling of heterotrophic bacteria to phytoplankton bloom development at different $\mathrm{pCO}_{2}$ levels: a mesocosm study. Biogeosciences (Spec Issue: Pelagic ecosystem $\mathrm{CO}_{2}$ enrichment studies) 5:317-359

Arnosti C (1995) Measurement of depth- and site-related differences in polysaccharide hydrolysis rates in marine sediments. Geochim Cosmochim Acta 59:4247-4257

Arnosti C (1996) A new method for measuring polysaccharide hydrolysis rates in marine environments. Org Geochem 25:105-115

Arnosti C (2000) Substrate specificity in polysaccharide hydrolysis: contrasts between bottom water and sediments. Limnol Oceanogr 45:1112-1119

> Arnosti C (2003) Fluorescent derivatization of polysaccharides and carbohydrate-containing biopolymers for measurement of enzyme activities in complex media. J Chromatogr B 793:181-191 
Arnosti C (2004) Speed bumps and barricades in the carbon cycle: substrate structural effects on carbon cycling. Mar Chem 92:263-273

Arnosti C (2008) Functional differences between Arctic sedimentary and seawater microbial communities: contrasts in microbial hydrolysis of complex substrates. FEMS Microbiol Ecol 66:343-351

> Arnosti C, Repeta DJ (1994) Extracellular enzyme activity in anaerobic bacterial cultures: evidence of pullulanase activity among mesophilic marine bacteria. Appl Environ Microbiol 60:840-846

Arnosti C, Durkin S, Jeffrey WH (2005) Patterns of extracellular enzyme activities among pelagic marine microbial communities: implications for cycling of dissolved organic carbon. Aquat Microb Ecol 38:135-145

Arrigo KR (2007) Carbon cycle: marine manipulations. Nature 450:491-492

Azam F (1998) Microbial control of oceanic carbon flux: the plot thickens. Science 280:694-696

Bauer M, Kube M, Telling H, Richter M and others (2006) Whole genome analysis of the marine Bacteroidetes 'Gramella forsetii' reveals adaptations to degradation of polymeric organic matter. Environ Microbiol 8:2201-2213

Benner R, Pakulski JD, McCarthy M, Hedges JI, Hatcher PG (1992) Bulk chemical characteristics of dissolved organic matter in the ocean. Science 255:1561-1564

Bold HC (1985) Algae. Prentice Hall, Englewood Cliffs, NJ

- Bray JR, Curtis JT (1957) An ordination of the upland forest communities of Southern Wisconsin. Ecol Monogr 27: 325-349

> Brown SH, Kelly RM (1993) Characterization of amylolytic enzymes, having both $\alpha-1,4$ and $\alpha-1,6$ activity, from the thermophilic archaea Pyrococcus furiosus and Thermococcus litoralis. Appl Environ Microbiol 59:2614-2621

Caldeira K, Wickett ME (2003) Oceanography: anthropogenic carbon and ocean $\mathrm{pH}$. Nature 425:365

Carlson CA (2002) Production and removal processes. In: Hansell DA, Carlson CA (eds) Biogeochemistry of marine dissolved organic matter. Academic Press, New York, NY, p 91-151

> Carlson CA, Morris R, Parsons R, Treusch AH, Giovannoni SJ, Vergin K (2009) Seasonal dynamics of SAR11 populations in the euphotic and mesopelagic zones of the northwestern Sargasso Sea. ISME J 3:283-295

Chin-Leo G, Kirchman DL (1988) Estimating bacterial production in marine waters from the simultaneous incorporation of thymidine and leucine. Appl Environ Microbiol 54:1934-1939

Clarke KR, Warwick RM (2001) Change in marine communities: an approach to statistical analysis and interpretation, 2nd edn. PRIMER-E, Plymouth

> Clarke KR, Somerfield PJ, Gorley RN (2008) Testing of null hypotheses in exploratory community analyses: similarity profiles and biota-environment linkage. J Exp Mar Biol Ecol 366:56-69

Cottrell MT, Kirchman DL (2000) Natural assemblages of marine proteobacteria and members of the CytophagaFlavobacter cluster consuming low- and high-molecularweight dissolved organic matter. Appl Environ Microbiol 66:1692-1697

Dar SA, Kuenen JG, Muyzer G (2005) Nested PCR-denaturing gradient gel electrophoresis approach to determine the diversity of sulfate-reducing bacteria in complex microbial communities. Appl Environ Microbiol 71:2325-2330

Davis CL (1992) Production of laminarinase and alginase by marine bacteria after starvation. FEMS Microbiol Ecol 86:349-356
Doney SC, Fabry VJ, Feely RA, Kleypas JA (2009) Ocean acidification: the other $\mathrm{CO}_{2}$ problem. Annu Rev Marine Sci 1:169-192

Engel A, Schulz KG, Riebesell U, Bellerby R, Delille B, Schartau M (2008) Effects of $\mathrm{CO}_{2}$ on particle size distribution and phytoplankton abundance during a mesocosm bloom experiment (PeECE II). Biogeosciences 5:509-521

Fabry VJ (2008) Marine calcifiers in a high $\mathrm{CO}_{2}$ ocean. Science 320:1020-1022

Fajon C, Cauwet G, Lebaron P, Terzic S and others (1999) The accumulation and release of polysaccharides by planktonic cells and subsequent bacterial response during a controlled experiments. FEMS Microbiol Ecol 29:351-363

> Fuhrman JA, Azam F (1982) Thymidine incorporation as a measure of heterotrophic bacterioplankton production in marine surface waters: evaluation and field results. Mar Biol 66:109-120

Fuller NJ, Marie D, Partensky F, Vaulot D, Post AF, Scanlan DJ (2003) Clade-specifc 16S rDNA oligonucleotides reveal the predominance of a single marine Synechococcus clade throughout a stratified water column in the Red Sea. Appl Environ Microbiol 69:2430-2443

- Glöckner FO, Kube M, Bauer M, Teeling H and others (2003) Complete genome sequence of the marine planctomycete Pirellula sp. strain 1. Proc Natl Acad Sci USA 100:8298-8303

Gordon DA, Giovannoni SJ (1996) Detection of stratified microbial populations related to Chlorobium and Fibrobacter species in the Atlantic Ocean and Pacific Ocean. Appl Environ Microbiol 62:1171-1177

> Grossart HP, Levold F, Allgaier M, Simon M, Brinkhoff T (2005) Marine diatom species harbour distinct bacterial communities. Environ Microbiol 7:860-873

Grossart HP, Allgaier M, Passow U, Riebesell U (2006a) Testing the effect of $\mathrm{CO}_{2}$ concentration on the dynamics of marine heterotrophic bacterioplankton. Limnol Oceanogr 51:1-11

Grossart HP, Czub G, Simon M (2006b) Specific interactions of planktonic algae and bacteria: implications for aggregation and organic matter cycling in the sea. Environ Microbiol 8:1074-1084

Hedges JI, Clark WA, Cowie GL (1988) Organic matter sources to the water column and surficial sediments of a marine bay. Limnol Oceanogr 33:1116-1136

Iglesias-Rodriguez MD, Halloran PR, Rickaby REM, Hall IR and others (2008) Phytoplankton calcification in a high$\mathrm{CO}_{2}$ world. Science 320:336-340

Joint I, Doney SC, Karl DM (2011) Will ocean acidification affect marine microbes? ISME J 5:1-7

Kähler P, Koeve W (2001) Marine dissolved organic matter: can its C:N ratio explain carbon overconsumption? DeepSea Res I 48:49-62

Liu JW, Weinbauer MG, Maier C, Dai MH, Gattuso JP (2010) Effect of ocean acidification on microbial diversity and on microbe-driven biogeochemistry and ecosystem functioning. Aquat Microb Ecol 61:291-305

Martinez J, Smith DC, Steward GF, Azam F (1996) Variability in ectohydrolytic enzyme activities of pelagic marine bacteria and significance for substrate processing in the sea. Aquat Microb Ecol 10:223-230

Mühling M, Woolven-Allen JA, Murrel JC, Joint I (2008) Improved group-specific PCR primers for DGGE analysis of the genetic diversity of complex microbial communities. ISME J 2:379-392

> Murray AE, Arnosti C, De La Rocha CL, Grossart HP, Passow U (2007) Microbial dynamics in autotrophic and heterotrophic seawater mesocosms. II. Bacterioplankton community structure and hydrolytic enzyme activities. Aquat 
Microb Ecol 49:123-141

Muyzer G, De Waal EC, Uitterlinden AG (1993) Profiling of complex microbial populations by denaturing gradient gel electrophoresis analysis of polymerase chain reactionamplified genes coding for 16S rRNA. Appl Environ Microbiol 59:695-700

Myklestad SM (1995) Release of extracellular products by phytoplankton with special emphasis on polysaccharides. Sci Total Environ 165:155-164

Nagata T (2000) Production mechanisms of dissolved organic matter. In: Kirchmann DL (ed) Microbial ecology of the oceans. Ecological and applied microbiology. John Wiley, Hoboken, NJ, p 121-151

Nausch M, Pollehne F, Kerstan E (1998) Extracellular enzyme activities in relation to hydrodynamics in the Pomeranian Bight (Southern Baltic Sea). Microb Ecol 36:251-258

Orr JC, Fabry VJ, Aumont O, Bopp L and others (2005) Anthropogenic ocean acidification over the twenty-first century and its impact on calcifying organisms. Nature 437:681-686

Painter TJ (1983) Algal polysaccharides. In: Aspinall GO (ed) The polysaccharides. Academic Press, New York, NY, p 195-285

Passow U (2002) Transparent exopolymer particles in aquatic environments. Prog Oceanogr 55:287-333

Piontek J, Lunau M, Handel N, Borchard C, Wurst M, Engel A (2010) Acidification increases microbial polysaccharide degradation in the ocean. Biogeosciences 7:1615-1624

Pomeroy LR, Williams PJleB, Azam F, Hobbie JE (2007) The microbial loop. Oceanography 20:28-33

Riebesell U, Zondervan I, Morel FMM (2000) Reduced calcification of marine planktonin response to increased atmospheric $\mathrm{CO}_{2}$. Nature 407:364-367

Riebesell U, Bellerby RGJ, Grossart HP, Thingstad TF (2008) Mesocosm $\mathrm{CO}_{2}$ pertubation studies: from organism to community level. Biogeosciences 5:1157-1164

Ries JB, Cohen AL, McCorkle DC (2009) Marine calcifiers exhibit mixed responses to $\mathrm{CO}_{2}$-induced ocean acidification. Geology 37:1131-1134

Rochelle-Newall E, Delille B, Frankignoulle M, Gattuso JP and others (2004) Chromophoric dissolved organic matter in experimental mesocosms maintained under different

Editorial responsibility: Fereidoun Rassoulzadegan, Villefranche-sur-Mer, France
pCO2 levels. Mar Ecol Prog Ser 272:25-31

Rost B, Riebesell U (2004) Coccolithophores and the biological pump: responses to environmental changes. In: Thierstein $\mathrm{H}$, Young J (eds) Coccolithophores, from molecular processes to global impact. Springer, New York, NY, p 99-127

Schulz KG, Riebesell U, Bellerby RGJ, Biswas H and others (2008) Build-up and decline of organic matter during PeECE III. Biogeosciences 5:707-718

> Simon M, Azam F (1989) Protein content and protein synthesis rates of planktonic marine bacteria. Mar Ecol Prog Ser 51:201-213

Sokal RR, Michener CD (1958) A statistical method for evaluating systematic relationships. Univ Kansas Science Bull 38:1409-1438

Steen AD, Hamdan L, Arnosti C (2008) Dynamics of highmolecular-weight dissolved organic carbon in the Chesapeake Bay: insights from enzyme activities, carbohydrate concentrations, and microbial metabolism. Limnol Oceanogr 53:936-947

- Tanaka T, Thingstad TF, Lovdal T, Grossart HP and others (2008) Availability of phosphate for phytoplankton and bacteria and of glucose for bacteria at different $\mathrm{pCO}_{2}$ levels in a mesocosm study. Biogeosciences 5:669-678

Vezina AF, Hoegh-Guldberg O (2008) Effects of ocean acidification on marine ecosystems: introduction. Mar Ecol Prog Ser 373:199-201

- Warren RAJ (1996) Microbial hydrolysis of polysaccharides. Annu Rev Microbiol 50:183-212

Weiner RM, Taylor LE II, Henrissat B, Hauser L and others (2008) Complete genome sequence of the complex carbohydrate-degrading marine bacterium, Saccharophagus degradans Strain 2-40T. PLoS Genet 4:e1000087

Weiss MS, Abele U, Weckesser J, Welte W, Schiltz E, Schulz GE (1991) Molecular architecture and electrostatic properties of a bacterial porin. Science 254:1627-1630

> Yamada N, Suzumura M (2010) Effects of seawater acidification on hydrolytic enzyme activities. J Oceanogr 66: $233-241$

Zhou J, Mopper K, Passow U (1998) The role of surface-active carbohydrates in the formation of transparent exopolymer particles by bubble adsorption of seawater. Limnol Oceanogr 43:1860-1871

Submitted: August 23, 2010; Accepted: May 26, 2011 Proofs received from author(s): September 6, 2011 